\title{
Managing Paradoxical Tensions During the Implementation of Lean Capabilities for Improvement
}

Maalouf, Malek Miguel; Gammelgaard, Britta

\author{
Document Version \\ Accepted author manuscript \\ Published in: \\ International Journal of Operations and Production Management
}

DOI:

10.1108/IJOPM-10-2014-0471

Publication date:

2016

License

Unspecified

Citation for published version (APA):

Maalouf, M. M., \& Gammelgaard, B. (2016). Managing Paradoxical Tensions During the Implementation of Lean Capabilities for Improvement. International Journal of Operations and Production Management, 36(6), 687-709. https://doi.org/10.1108/IJOPM-10-2014-0471

Link to publication in CBS Research Portal

\section{General rights}

Copyright and moral rights for the publications made accessible in the public portal are retained by the authors and/or other copyright owners and it is a condition of accessing publications that users recognise and abide by the legal requirements associated with these rights.

\section{Take down policy}

If you believe that this document breaches copyright please contact us (research.lib@cbs.dk) providing details, and we will remove access to the work immediately and investigate your claim. 


\title{
Managing Paradoxical Tensions During the Implementation of Lean Capabilities for Improvement
}

Malek Miguel Maalouf and Britta Gammelgaard

\author{
Journal article (Post print version)
}

CITE: Managing Paradoxical Tensions During the Implementation of Lean Capabilities for Improvement. / Maalouf, Malek Miguel; Gammelgaard, Britta. In: International Journal of Operations and Production Management, Vol. 36, No. 6, 2016, p. $687-709$.

DOI: 10.1108/IJOPM-10-2014-0471

Uploaded to Research@CBS: April २०17 


\title{
Managing paradoxical tensions during the implementation of Lean capabilities for improvement
}

\begin{abstract}
Purpose - Through the identification and investigation of the organisational paradoxes in lean, the paper aims to deepen the understanding of lean implementation intricacies, and contribute to sustaining lean in companies.

Design/methodology/approach - Case study based on semi-structured interviews with participants in lean conversion from three companies in Denmark. The companies come from different business sectors: Public transport, Healthcare, and Finance.

Findings - This study identifies three types of organisational paradoxes in lean: organising, performing, and belonging. The study also points to a range of managerial responses used for dealing with the three paradoxes and facilitating lean transformation.

Research implications/limitations - This is a theory development paper which increases our understanding regarding the role of the organisational paradoxes in facilitating or hindering lean transformation.

Practical implications - The study generates insights which help managers identify and deal with the individual motivations for opposing lean improvement practices, and thus facilitates lean transformation.
\end{abstract}

Originality/value - This study adds clarity to the process of managing lean implementation by identifying three different motivations for people to oppose lean transformation. The study also recommends managerial actions for dealing with each situation.

Keywords Lean, Continuous Improvement, Paradox, Organisational paradox, Tension, Denmark

Paper type Research paper 


\section{Introduction}

The lean system involves radical organisational and process change (Smeds, 1994), that spans the entire company from business strategy to product development and production (Womack, Jones and Roos, 1990). As an approach to organisational change, lean and its predecessor just-in-time can be seen as a continuous process of creation of paradoxes (Eisenhardt and Westcott, 1988). Within this context, organisational paradox "denotes contradictory yet interrelated elements-elements that seem logical in isolation but absurd and irrational when appearing simultaneously" (Lewis, 2000b, p. 760). Indeed, lean philosophy represents a counterintuitive thinking relative to the capital-intense mass production system with its large batches and dedicated machines (Womack, Jones and Roos, 1990). As an organisational form, lean departs from the traditional reliance on a rigid division of labour and standardised job tasks (Dankbaar, 1997; Adler et al., 1999; Mullarkey, et al., 1995). For instance, lean and just-in-time practices rely on competing processes and designs, such as increasing employee empowerment as well as adopting statistical processes and controls (Eisenhardt and Westcott, 1988). These two opposing yet complementary features of lean work design accentuate structural tensions within organisations (Smith and Lewis, 2011). Such structural tensions are typically referred to in the organisational literature as an organising paradox, which emerges as organisations create competing designs in order to enhance performance (Lewis, 2000b).

In this paper, we aim to add clarity to the process of lean implementation and generate insights that facilitate lean transformation through the identification and investigation of the organisational paradoxes in lean. This work focuses on tools and practices for creating structures for Lean improvement and building Lean organizational capabilities such as Operating standards, 5S, and Cross-functional teams (Langstrand and Drotz, 2015; Hines et al., 2004; Pavnaskar, Gershenson, \& Jambekar, 2003). We adopt the paradox theory (Smith and Lewis, 2011; Lewis, 2000b; Jarzabkowski, 2013; Lüscher and Lewis, 2008; Poole and Van de Ven, 1989; Quinn and Cameron, 1988) as a framework for increasing our understanding of the intricacies of the building of lean organisational capabilities. Within this context, Quinn and Cameron (1988, preface) state that "we are convinced not only that organisational paradox provides a rich metaphor for understanding organisational phenomena, but that it can lead to a more comprehensive and complex view of organisations and their management than has been previously available". 
The paradox theory identifies four types of organisational paradoxes: organising, performing, belonging and learning (Smith and Lewis, 2011), which are created and accentuated by organisational change (Quinn and Cameron, 1988), such as lean and just-in-time implementation (Eisenhardt and Westcott, 1988). Moreover, organisational paradoxes are located in social interactions and amplified by human cognition, fuelling a dynamic process of change that leads to positive or negative outcomes (Quinn and Cameron, 1988). Managerial responses are needed in order to break the negative dynamics and obtain positive outcomes (Jarzabkowski, 2013; Smith and Lewis, 2011; Lewis, 2000b).

As such, the research design of this paper is based on applying the paradox theory to investigate the organisational paradoxes emerging from the implementation of a range of lean tools in three Danish companies. This study is exploratory in a sense that it uses the paradoxical framework as a metaphor (Foropon and McLachlin, 2013) for mapping the various categories of organisational paradoxes in lean, and for generating insights about their roles in facilitating or hindering lean conversion. The companies are in the process of sustaining and consolidating lean capabilities, and have employed a range of managerial actions with varying degrees of success. They come from different branches of industries and services - healthcare, financial, and public transport -, which enables the researcher to investigate lean paradoxes across three different organisational contexts. More specifically, this lean study addresses the following research question:

What organisational paradoxes are salient during the building of lean structures of improvement and how have they been managed?

In this study, we focus on the paradoxical nature of tensions and, as such, the terms tension and paradox are used interchangeably. The next section uses the four categories of organisational paradoxes as a lens for reviewing the extant lean literature, and gives examples of each paradox extracted from the reviewed lean studies. The third section presents the paradoxical framework used for unpacking and investigating the organisational paradoxes. The subsequent sections present the research method of the study, findings, discussions, implications, and conclusions.

\section{The four categories of organisational paradoxes in Lean}

Hines et al. (2004) argue that lean exists at two levels: strategic and operational. The strategic thinking with focus on customer value applies everywhere, while the operational shop-floor tools do not. From a strategic point of view, companies can integrate a range of practices and tools without 
contradicting the core objective of lean; that is to provide customer value (Hines et al., 2004; Womack and Jones, 2003). As such, tools and practices - such as Workplace housekeeping or 5S (Green et al., 2010; Saurin et al., 2011), Standardised work (Saurin et al., 2011; Adler et al., 1999), Visual Management (Saurin et al., 2011), Cross functional teams (Sezen et al., 2012), and Value Stream Mapping, Lean flow, and Load levelling (Pavnaskar et al., 2003; Sezen et al., 2012) - are part of the operational level that companies use to promote lean thinking, create structures for improvement and build organisational lean capabilities (Langstrand and Drotz, 2015). These lean tools are the instruments of change which unfreeze the current situation in organisations, accentuating the organisational paradoxes (Smith and Lewis, 2011).

In this section, we use the four categories of organisational paradoxes (Smith and Lewis, 2011; Lewis, 2000b; Lüscher and Lewis, 2008) as a lens for reviewing the extant lean literature, and we give examples of the four types of paradoxes extracted from the reviewed lean studies. The paradox theory identifies four categories of organisational paradoxes representing core activities of organisations: the paradoxes of organising are embedded in organisational designs and processes; the paradoxes of belonging are related to tensions of identity and interpersonal relationship; the paradoxes of performing emerge from competing goals and objectives; and finally, the paradoxes of learning are related to tensions between old and new knowledge (Smith and Lewis, 2011).

First, the paradoxes of organising surface as organisations create competing designs and processes in order to enhance performance (Lewis, 2000b). In fact, lean work design entails competing elements as it contains features of both mechanistic and motivational designs: the mechanistic design is grounded in the scientific management and oriented toward process simplification and efficiency, yet the motivational design is grounded in organisational psychology and associated with continuous learning, greater job responsibility, job rotation and teamwork (Adler and Borys, 1996; Cullinane et al., 2013; Cooney, 2002;).

Second, the paradoxes of belonging reflect tensions of identity and relationships, and arise between the individual and the collective (Lewis, 2000b). The belonging paradoxes intensify as actors make decisions about how much time and effort to invest in the group. On the one hand, groups become more effective if the individuality of their members is respected. On the other hand, individuality is a self-referential loop that can disrupt group decision and performance (Smith and Lewis, 2011). In their study related to implementing lean in product development, Karlsson and Åhlström (1996) identify a situation fostering a belonging paradox embedded in the creation of cross-functional 
teams. Specifically, the authors observe that finding the right person for the right task and splitting loyalty when contributing to different tasks are some of the hindering factors for achieving crossfunctional integration. In this case, the paradox of belonging accentuates during lean transformation as employees attempt to make sense of two competing yet interrelated roles: team role versus functional role (Lüscher and Lewis, 2008).

Third, the paradoxes of performing typically emerge from conflicting demands among different stakeholders (Lewis, 2000b). Moreover, organisational change tends to exacerbate the tensions of performing by fostering competing measures of managerial success (Smith and Lewis, 2011). Within this context, lean entails pursuing multiple and competing dimensions of corporate performance, such as lower costs, short cycle for development of new products, superior quality, and increased flexibility (Nawanir et al., 2013; Modig and Åhlström, 2012; Shah and Ward, 2003; Adler et al., 1999; Womack, et al., 1990). Finally, a common factor of the learning paradoxes is the ability to assimilate a new knowledge, which enables actors to adjust to variations and change (Smith and Lewis, 2011). As such, lean calls for learning more professional skills and applying these in a team setting rather than achieving higher levels of technical proficiency in narrower areas of specialisation (Womack, Jones, and Roos, 1990; West and Burnes, 2000; Lee et al., 2000). Namely, "the paradox is that the better you are at teamwork, the less you may know about a specific, narrow specialty that you can take with you to another company or to start a new business" (Womack, Jones, and Roos, 1990, p. 14). A situation is thus created where the learning paradox is made salient among actors (Lewis, 2000b).

\section{The analytical framework}

The analytical framework used in this study draws heavily on the three-part paradoxical framework advanced by Lewis (2000b). The first part of the Lewis framework involves mapping the two opposing poles of paradoxes - such as control versus autonomy or working in teams versus working in functions - and their underlying tensions. The underlying tensions are either individual cognitive structures such as the rational either/or mental frames (Lewis, 2000b) or organisational factors such as contradictory or mixed messages (Putnam, 1986). The either/or mental frame is the basis of human rationality, which leads to choosing one pole of a paradox and labelling the other pole bad (Quinn and Cameron, 1988). Contradictory messages denote inconsistencies between statements or between verbal and nonverbal responses, which appear during social interactions. They accentuate paradoxical tensions as actors struggle to find meaning in ambiguous messages (Putnam, 1986). 
The second part of the framework concerns the individual defensive mechanisms that reduce embarrassment and anxiety (Argyris, 1988). For instance, projection is a defensive mechanism which entails blaming the other group for the bad performance or the persistence of problems (Smith and Berg, 1987; Vince and Broussine, 1996). Although the defensive mechanisms reduce embarrassment and anxiety, they are likely to reinforce paradoxical tensions (reinforcing cycles) in the long run as actors get stuck in their either/or mental frame (Lewis, 2000b). The third part focuses on the responses to the reinforcing cycles associated with paradoxes. For instance, confronting paradoxes is one of the managerial responses that explores and discusses the underlying tensions by helping actors construct a more accommodating understanding of the paradoxical phenomenon (Smith and Berg, 1987; Vince and Broussine, 1996). On the other hand, responses such spatial or temporal separation of the two poles of paradox help actors identify synergies between opposites by making explicit how one pole of the paradox sustains the other (Poole and Van de Ven, 1989). The main outcome of the management of paradoxes is the change from the either/or to a both/and mental frame. Because the either/or logic is based on the splitting of tensions and polarities, it may lead to lack of creative tensions. On the other hand, the both/and logic or perspective is based on the identification of synergies creating virtuous circles of change (Lewis, 2000b).

Figure 1 summarises and depicts the analytical framework used in this study. To unpack lean paradoxes, we examine their underlying tensions, the defensive mechanisms and reinforcing cycles, the managerial responses and the outcomes.

\section{Insert *Figure 1 - The analytical framework* about here}

\section{Research Method}

Case research is recommended for exploratory studies aiming to build theories (Eisenhardt, 1989). This study is exploratory and aims to explain why and how the organisational paradoxes in lean entail positive or negative outcomes (Yin, 2009). The types of paradox we are investigating are mainly ignited and amplified by human cognition (Lewis, 2000; Smith and Lewis, 2011). Therefore, individuals are the main source of data and the unit of analysis of the lean transformation process of this study. 


\section{Case selection}

Selecting cases is an important element of building theories from case study. In case research, the selection of cases is achieved according to theoretical or purposive sampling rather than statistical sampling (Glaser and Strauss, 1967). The purposive sampling is based on theory and assumes that cases are not chosen randomly (Eisenhardt, 1989). In this study, the three companies were selected because they had experience with lean implementation and were known to the authors for their effort to sustain lean. The companies were under pressure to improve performance and were implementing lean as a philosophy for change. They started lean implementation with a dominant top down approach, then adjusted the course of lean transformation and adopted a more participatory approach, which allowed for more bottom-up involvement in designing the content and pace of lean transformation. The change of approach toward lean implementation enables the researcher to investigate two opposing yet complementary approaches to lean implementation with varied effects on organizational processes, designs, goals and interpersonal relationships.

Table 1 presents a brief description of each company and the units where the data were collected, the tools involved in lean implementation, and the data sources.

\section{Insert *Table 1. Case companies and data sources* about here}

\section{Data collection}

The case analysis is based on data from semi-structured interviews with a range of informants from the three case companies. The selected informants are employees, managers, senior managers, and consultants with different backgrounds and experiences. The interviews ranged from half an hour to one and a half hours, and they were taped and transcribed in order to facilitate later analysis and reflection. An interview protocol with three themes was used as guide during the interviews (Kvale, 1983): one general theme about the informant background and involvement in lean (What is your position and experience/role in lean implementation?), one theme covering the different types of challenges encountered during lean implementation (What are the challenges and tensions that you or your unit face during lean implementation?), and one last theme probing the managerial responses for dealing with these challenges and the outcomes (What are the actions taken for dealing with these challenges and what are the outcomes?). 
As for the number of questions and interviews, the similarities and differences of stories among informants gave us some degree of confidence about the validity of knowledge claims (Kvale, 1983; Glaser and Strauss 1967). As for other sources of evidence, site visits and direct observations were also part of the data collection. Direct observations of visual management sessions, meetings and discussions were used to enrich the experience of the researcher and facilitate the understanding of the context surrounding lean implementation.

\section{Data Analysis}

Data analysis involves both within-case and cross-case analysis: The within-case analysis focuses on the emerging constructs and their relationships within each single case, while the cross-case analysis compares and contrasts the patterns emerging from the individual cases (Eisenhardt, 1989). In the next sections, we present the process adopted for data analysis in this study.

\section{Within case analysis}

The within case analysis followed the three steps of the analytical framework. That is, the analysis started with a pre-existing list of themes and their relationships (four types of organizational paradoxes, underlying tensions, defensive mechanisms, managerial responses and outcomes) based on the extant paradox literature. As such, by examining the interviews transcripts, we searched for patterns and descriptions related to the four types of organizational paradoxes. Then, we identified the underlying tensions, the reinforcing cycles, and the managerial responses/outcomes associated with each paradox.

For instance, the paradoxes of organizing were identified in citations reflecting tension, conflict and confusion related to changes in process and organizational design with impact on employees' autonomy and creativity (such as "people want to implement standards but they are afraid of losing the influence and the decision power over their work"); the paradoxes of belonging were observed in citations describing tensions related to teamwork, work identity and interpersonal relationships (such as "the implementation of lean has increased the cross functional cooperation among different group of employees; this cooperation has sometimes generated attrition between different approaches for performing the same task"); and the paradoxes of performing were located in sentences reflecting tensions or conflicts between two competing objectives or goals (such as "implementing standards increases the amount of work in the short run, but the benefits come later; however, it can be a problem to find time for implementing standards"). As for the underlying tensions, they were present in citations discussing beliefs and dominant mental frames as well as 
organizational factors which ignite and sustain paradoxical tensions (such as "following standards is always a challenge because the employees are evaluated every day; it generates permanent tension and employees say: shall we be evaluated every day?", which depicts a mental frame related to performance evaluation associated with the implementation of lean standards). The defensive mechanisms were mostly spotted in citations explaining people reactions to the proposed changes (such as "we are not robots" and "I can do better than standard"). Finally, managerial actions and outcomes were identified as we probed people actions for dealing with persistent tensions and improving individual and organizational performance (citations such as "involvement is the key to promoting the acceptance of lean standards as the employees are part of the solution" depict a managerial action, and citations such as "when there is a performance gap and the pressure mounts on us from top management, then we have to deliver and I can't focus on lean projects; it is a difficult decision but the fact is that we end up not focusing on lean projects" depict an outcome).

In total, we identified 24 citations of organising paradoxes, 15 of performing paradoxes and 14 of belonging paradoxes in the 27 interviews in the three companies. Table 2 contains the findings and the number of informants who identified each finding. It is important to mention that some informants described a paradoxical situation (paradox, underlying tensions and defensive mechanisms) without elaborating on its managerial responses and outcomes. In this case, the connections between paradox and managerial responses/outcomes were made as we compared citations from other informants. For instance, in Table 2, 24 informants reported the organizing paradox while 19 of them elaborated on the managerial responses and outcomes.

\section{Cross case analysis}

In cross-case analysis, we compared and contrasted the themes that had emerged from the within case analysis (Miles and Huberman, 1994; Eisenhardt, 1989). Similar themes were aggregated into three cross-case patterns, which constituted the basis for elaborating the contributions and implications of this study. The three cross-case patterns were identified through multiple iterations between data and literature, which helped capture the content of the data at different level of abstraction by referring to similar findings in the existing literature. For instance, the first cross pattern emerged as informants frequently associated the resistance to lean implementation with the paradoxes and tensions identified in this study. This association between resistance to lean and paradoxical tensions was also echoed by the extant lean literature. 
Two persons were involved in the analysis and identification of patterns: author and co-author (Eisenhardt, 1989). Through multiple literature reviews and discussions, the discrepancies between the two coders were settled and a clear protocol established. Moreover, discussions with key players (member checks) helped validate our findings and settle differences related to the interpretations of the data (Lincoln and Guba, 1985). These key players have a considerable technical expertise about lean tools and practices as well as strategic orientation due to their senior positions. The informants who provided the member checks generally agreed with the substance of the analysis and could recognize the presence of three types of paradoxes among employees and managers. However, member checks also revealed that middle and top managers were less aware of the impact of their actions on the different types of paradoxes or on people's resistance to lean transformation, which is somehow reflected in the second and third cross patterns of this study.

\section{Findings}

Our within-case findings are organised according to the analytical framework. As such, for each paradox we present the underlying tensions, the defensive mechanisms and reinforcing cycles, the managerial responses, and the outcomes. In this study, we identified three organizational paradoxes in lean: organizing, performing, and belonging. As for the learning paradoxes, it was difficult to observe them in isolation in the data. This fact is supported by previous studies on paradoxes (Jarzabkowski et al., 2013; Lüscher and Lewis, 2008), which also identified the paradoxes of organizing, performing, and belonging, and considered the paradox of learning as underpinning tension sustaining the other three types of paradoxes (Jarzabkowski et al., 2013). As for the management of the organisational paradoxes in lean, we identified a repertoire of managerial responses that include temporal, spatial separation, and goal setting (performing paradoxes), coaching/mentoring, and facilitation of group discussions (belonging paradoxes), and employee involvement, and experimentation (organising paradoxes). In the next sections, we present our within-case analysis followed by discussions and implications of the cross-case patterns.

\section{The paradox of performing}

The paradox of performing emerges as actors seek to allocate their effort and time between two opposing yet interrelated and complementary objectives (Lewis, 2000b). That is, allocate time and effort between daily activities (short term objectives) and lean improvement projects (long term objectives). The following citations and reactions depict such tensions among actors: "When should we focus on short term results or long term results, and what the balance is? is always a dilemma" 
(Transcript Company A); "couldn't I be allowed to do my daily job instead of lean stuff?"(Transcript Company B), and "implementing standards increases the amount of work in the short run, but the benefits come later; however, it can be a problem to find time for implementing standards" (Transcript Company B). Repenning and Sterman (2001) have labelled this tension as the paradox of working harder (pursuing short term objectives) versus working smarter (pursuing long term objectives). According to Repenning and Sterman (2001), the performance of any process depends on two factors: the amount of time spent working (work harder) and the capability of the process used to do that work (work smarter). As such, lean tools and practices are considered process capability boosters (long term objectives) as they offer a way for identifying and eliminating waste or non-value added activities from the value stream (Womack et al. 1990).

According to Repenning and Sterman (2001), the paradox of performing unfolds according to the following sequence of events. In the event of a performance gap, managers are under pressure to increase performance by relying on two options: work harder or work smarter. The work harder option means that managers pressure people to spend more energy doing work. The second option to close a performance gap is to improve the capability of the process (work smarter). Yet the working smarter option often involves a substantial delay between investing in an improvement initiative - such as lean - and reaping the benefits. It is thus not surprising that managers frequently use the work harder option to solve pressing problems. This situation is paradoxical because as managers use the option work harder, employees increase the amount of time spent working, and cut the time spent on lean improvement projects. As a consequence, process capability decay and the performance gap grows even more, forcing a further shift toward working harder (Repenning and Sterman, 2001). The analysis identified this paradox of performing in companies A and B.

\section{Underlying tensions}

The participants generally agreed that over-emphasising one of the poles of the paradox would increase business vulnerability, and reduce long term adaptability. One manager depicted the performing tensions as "sometimes it is about achieving quality and quantity goals, which can be contradictory; if we focus only on quantity, it can affect the quality and vice versa; it is about continuous dialogue between the two possibilities" (Transcript company A). However, contradictory and mixed messages (Putnam, 1986) from top management contributed to intensifying and even perpetuating the paradox of performing: on the one hand, top management had repeatedly reiterated that lean projects are crucial for the long term competitiveness of the 
company, yet employees were often required by top management to reprioritise their time and focus on meeting daily activities deadlines (short term goals). According to one informant, "we don't have time to finish our $5 S$ project; top management thinks that it's good to have $5 S$, but we have to deliver our daily projects" (Transcript Company A), and another informant noted that "the employees don't have time to do what they are asked to do; they don't have time to participate in daily improvement meetings or to follow the $5 S$ procedures; it is a challenge for management to communicate effectively, and help them achieve balance between daily activities and lean projects" (Transcript company B).

\section{Reinforcing cycles}

In reaction to the mixed messages, actors often resorted to the work harder option by focusing on daily activities. The paradox literature categorises this behaviour as regression, which involves resorting to understandings or actions that have provided security in the past (Lewis, 2000b). Indeed, work harder is considered the safe option as it quickly closes the performance gap and reduces top management pressure. This fact seemed only to exacerbate the problem and increase frustrations among actors. One middle manager expressed his frustration as he was not able to break this vicious cycle: "top management wants us to improve our processes; yet daily pressure makes the employees focus on meeting their deadlines, and I can't tell my employees to do otherwise. I can't delay important deadlines" (Transcript Company A). Another manager described the regression as "when employees are under pressure, they shift immediately their focus in order to meet the deadlines, and deliver what it is expected from them" (Transcript company B).

\section{Managerial responses and outcomes}

Dealing with the paradoxes of performing often involved defensive responses. Defensive responses are based on splitting the two poles of paradox spatially or temporally (Poole and Van de Ven, 1989). As such, the separation of the two poles of the paradox provides short term relief enabling actors to identify more enduring synergies between the two poles of the paradox (Jarzabkowski et al., 2013). In spatial separation, opposing elements or activities are allocated across different organisational units or teams (Poole and Van de Ven, 1989). According to one manager: "We divided our employees between two groups: firefighters and process improvement teams. The firefighters deal with daily activities while the process improvement teams can have more time for planning and improvement" (Transcript Company B). 
In temporal separation, one pole of the paradox is assumed to hold during one time period and the other during a different time period. Consequently, employees are required to switch between work harder and work smarter activities sequentially. More specifically, managers demanded that employees divide their time between daily activities and lean projects by dedicating a percentage of their work effort to lean projects. According to one manager: "We agreed that employees should dedicate 20\% of their time to lean improvement projects" (Transcript Company B). Indeed, managers included lean projects (the work smarter projects) in the annual performance appraisals. As such, managers used the goal setting portion of performance appraisals in order to boost the work smarter option (lean projects). According to one informant, "we need to produce a certain number of lean methods and standards, and every quarter we have to report to management how many standards we can complete; we have to divide our time; we have to be careful that we have some time to project and time to do improvement, not putting $100 \%$ in one activity" (Transcript Company A). In the human resource literature, goal setting is one of the established theories of motivation, which emphasises that goals can significantly influence individual and team performance (Locke and Latham, 1990).

By separating the two poles of paradoxes, either temporally or spatially, lean managers sought to identify synergies and create meaning that could accommodate the two contradictory yet interrelated goals: working harder versus working smarter. According to one manager, some employees now understand that "standards can make sense in the long run; it is time consuming now; but in the long run it will pay back" (Transcript Company B). Similarly, one informant explained the complementary relationship between the two types of activity: "the idea is that when we use standards we reduce the waste in the process; consequently, there are more resources to be invested in creative projects" (Transcript Company B). Another informant attempted to make sense of the paradox by concluding that "people understand that standards can help them but they know that it is a long trip" (Transcript Company A). Yet the analysis indicates that sustaining the effort dedicated to lean projects was sometimes elusive, as mixed messages and persistent pressure from top management often made the work harder option prevail. One informant explained this situation: "when there is a performance gap and the pressure mounts on us from top management, then we have to deliver and I can't focus on lean projects; it is a difficult decision but the fact is that we end up not focusing on lean projects" (Transcript Company A). 


\section{The paradox of belonging}

The paradox of belonging rotates around tensions of identity and interpersonal relationships, and emerges as actors take on new roles or attempt to cope with changing relationships (Lüscher and Lewis, 2008). At company C, lean transformation had a direct impact on actors' roles as team leaders were required to act as process and operations managers rather than technical experts. For instance, one manager has described the belonging paradoxes in sentences such as: "Specialists value what they do and their prestige is based on what they have achieved; now they have to be process managers rather than specialists; this fact has challenged their work identities", and "Specialists are good at what they do; now they have to change their work process so they don't feel special anymore; this generates a lot of tensions among them" (Transcript Company C). On the other hand, at companies A and B, the paradox of belonging accentuated as lean practices increased cross-functional linkages between different functional roles along the value stream. According to one director at company A, "the implementation of lean has increased the cross functional cooperation among different group of employees; this cooperation has sometimes generated attrition between different approaches for performing the same task" (Transcript company A).

\section{Underlying tensions}

At company $\mathrm{C}$, one informant explained the tension as people attempted to take on new roles: "people want to hold on the old role as firefighter because it has been the source of their prestige within the company; it's about letting go of the old role and embracing the new role" (Transcript Company C). Another informant further explained the challenge: "it's about skills and competences because there are a lot of new things they have to learn; they have to learn how to become an operations manager that follows the daily operational plan, how to allocate workload to each employee... they should not only be technical leaders but also lean consultants" (Transcript Company C). As for companies A and B, the implementation of lean flow accentuated the paradox of belonging between two functions and roles cultivating different work identities. According to one manager, "some of our technicians are disciplined as their education and background direct them toward a more structured approach for problem solving; on the other hand, some of our researchers face difficulties in adopting a more structured approach in performing their tasks" (Transcript Company A). In fact, the anxiety stemming from the creative people - who had cultivated a work environment based on creative ideas and non-repetitive processes - had increased as they attempted to use lean standards and performance indicators in cross-functional projects with 
the technical people, who had fostered an identity based on discipline and structure in approaching their daily work.

\section{Reinforcing cycles}

As the paradoxes of belonging increased anxiety among actors, actors often used projection as a defensive mechanism: projection entails blaming the other group or function for the bad performance or the persistence of problems (Lewis, 2000b; Smith and Berg, 1987). One informant explained this situation between two groups of employees: "there are two main groups of employees with different values and identities: the mechanics in the shop floor and the traffic planners; the two groups are often blaming each other for organisational problems; the planners value a strict schedule while mechanics value the quality of the service even though this means spending extra time on repairs" (Transcript Company B). In some critical instances, the paradoxes of belonging had accentuated to the point where different groups within the same organisation reverted to splitting as a defensive mechanism. Splitting over-emphasises contradictions and masks similarities by forming subgroups accentuating the "we/they" distinctions. According to the lean manager, "some business groups were acting like kingdoms where external interference is not welcomed, and benchmark or learning from other sites is avoided"' (Transcript Company B).

\section{Managerial responses and outcomes}

Coaching/mentoring and facilitation of group meetings and discussions were often used in order to bring tensions between two functions or groups to the surface, and to promote acceptance of the paradoxes of belonging. Specifically, as tensions flared among actors in the beginning of lean flow implementation, lean managers and external consultants facilitated group discussions in order to help break the vicious cycles associated with the paradoxes of belonging. That is, each time members of a group move toward another group, they risk losing their individuality and the support of their group. Yet as members reveal themselves to the other group, they fear rejection, fostering a double bind (Lüscher and Lewis, 2008). According to one manager who facilitated various sessions of group discussions: "every time mechanics and traffic planners were blaming each other for a problem, we put both parties together and we looked closely at the problem; this fact has increased the flow of communication between the two functions; people now understand each other's challenges and problems; and things started to change until it was no longer us against them" (Transcript Company B). Another manager explained that "it is important to mix people from different background so they can learn from each other and complement each other's skills" (Transcript Company A). The literature reveals that group discussions facilitate cooperation by 
offering group members the opportunity to develop, and increases the commitment to cooperate by reducing the fear of exploitation and risk associated with the cooperative choice (Bouas and Komorita, 1996).

Dealing with the paradox of belonging also involved coaching and mentoring of employees as they attempt to take on new lean roles. In the human resources literature, coaching and mentoring are considered managerial development practices (Noe, 2001). Coaching and psychotherapy are based upon similar theoretical constructs (Hart, Blattner, and Leipsic, 2001). As such, coaching can influence the cognitive and behavioural repertoire of individuals (Segers et al., 2011), and help them deal with paradoxical tensions (Denison et al., 1995). According to one manager, mentoring and coaching are offered to the most critical cases among employees attempting to take on new lean roles. However, in some cases, employees are moved to other positions within the company where lean's impact on structures and roles is less radical. The manager explained that "we invest in coaching and mentoring where an external consultant follows and helps the employee; we use also a maturity model where we assess the development of the employees; however, sometimes we can see that, even after many attempts, this employee is not the right man for this new role; so we have to find something else for him elsewhere" (Transcript Company C).

\section{The paradox of organising}

The paradoxes of organising have consistently rotated in the three companies around tensions between control and autonomy/creativity. On the one hand, the implementation of lean operating standards is something to be expected in lean companies because standards increase efficiency and support the elimination of waste $(m u d a)$ - a core feature of lean philosophy. On the other hand, companies need employees' autonomy and creativity for solving unexpected problems and dealing with future challenges (Adler and Borys, 1996). As such, the paradoxes of organizing were identified in citations related to changes in process and organizational design, such as: "People want to implement standards, but they are afraid of losing the influence and the decision power over their work" (Transcript Company A); "I don't like the idea to get imposed a rigid set of standards on my work process; I would rather prefer a bottom up approach to come up with suggestions and build my own standards" (Transcript Company B); and "Some people think that by implementing standards everything will become rigid" (Transcript Company A). 


\section{Underlying tensions}

In this study, the paradoxes of organising were accentuated in the three companies as lean standards had a direct impact on the autonomy and creativity of the employees. One manager described this organizing paradox: "I want to give my employees autonomy, but I want to avoid the chaos; and, when we talk about standards, there are always different ways among people of understanding what a standard is; there is always an endless discussion in the team about how much a standard is good and when a standard becomes a bad thing” (Transcript Company A). Another informant described the underlying tension as "people from Research and Development are innovative and they think that lean and Research might not be a good combination; however, it can be an advantage to keep the innovative spirit together with a structured daily work" (Transcript company A). Moreover, one informant at Company B stated that "following standards is always a challenge because the employees are evaluated every day; it generates permanent tension and employees say: shall we be evaluated every day?".

\section{Reinforcing cycles}

Reaction formation (Lewis, 2000b), which entails manifesting the feeling or practice opposite to the threatening one, was manifested by actors as the anxiety had increased in reaction to the paradoxes of organising. Informants described actors' reactions to the organising paradox in citations such as "we are not robots"; "I can do better than standard and nobody should tell me how to do my work" (Transcript Company B); and "I want to do it my own way" (Transcript Company A). Indeed, people often attempted to emphasise the shortcomings of lean standards and prove to management that implementing standards is not the optimal solution for increasing performance. One informant reported that some employees attempted to "beat the standards" (Transcript Company C), by demonstrating to their managers that "lean standards" were less productive than "individual standards".

\section{Managerial responses and outcomes}

Employee involvement and experimentation were used for dealing with the paradoxes of organising. Employee involvement and experimentation increased acceptance of the paradox, which entailed awareness that standards would not curb autonomy or harm creativity. That is, standards increased the willingness among actors to identify synergies where lean standards support autonomy and creativity rather than inhibiting them (Adler and Borys, 1996). One manager mentioned that in order to promote the acceptance of the organising paradox, " $a$ lot of experimentation and involvement were needed" (Transcript Company A). Employee involvement 
was often mentioned in the interviews as a key factor for promoting the acceptance of lean standards among employees. According to one informant, "involvement is the key to promoting the acceptance of lean standards as the employees are part of the solution" (Transcript Company A). Another informant explained that "involving the most resistant people is important for the success of change; in fact, our experience shows that other employees listen to them, and when they're convinced, they turn out to be passionate about it" (Transcript Company C). Yet one manager repeated that "it is important to involve each and every worker; ask their opinions and communicate continuously with them; a lot of training and involve the leadership in all phases of communication; the employees will buy in when it makes sense for them" (Transcript Company C). By intensively involving employees in the construction and improvement of lean standards, managers have been able to reduce the fear of standards within their organisations. Employee involvement or participation is defined in the literature as a conscious effort by managers to provide more opportunities for individuals or groups at a lower level in the organisation to have a greater influence in one or more areas of organisational performance (Glew, O'Leary-Kelly, Griffin, and Fleet, 1995). As such, employee involvement is an important construct of organisational life, which contributes to increasing organisational effectiveness (Shadur, Kienzle, and Rodwell, 1999).

As for experimentation, one manager explained that "it is important to establish an experimentation and continuous improvement environment. As we say to our employees: the standard is here until we find a better one" (Company A). Another informant explained: "we frequently say to lean people that standard is not sacred but it can be improved by you" (Transcript Company A). According to one manager, the shift in the mental model in Company A was noticed when employees started to realise that "standards can help us in performing our tasks; creativity is not gone because of standardisation; standards can make life easier for us, but standards that make sense as we standardise the repetitive parts of the process" (Transcript Company A). During the process of experimentation of standards, sceptical employees started to realise that standards indeed can make sense. The manager explained this new understanding among employees as follows: "If there is something that can be understood differently within the team and it is repeated many times, then it makes sense to make standards of this activity". As such, "it is not necessary that creativity is gone when we implement standards; standards can support us in our daily activities without killing our creativity" (Transcripts Company A). Experimentation generates trial-and-error learning, which occurs when an organisation carries out regular activities, compares outcomes with targets, and then revises its routines as needed (Cyert and March, 1963). Experimentation can indeed be a 
way of negotiating the various tensions and conflicts in organisations undergoing change by moving from an either-or to a both-and organisational schema (Rerup and Feldman, 2011), thus facilitating the acceptance of the paradoxes of organising (Lüscher and Lewis, 2008). However, despite a consensus that lean standards could make sense by facilitating the creative tasks, some employees still harboured desires for full autonomy and frequently attempted to circumvent lean standards.

Table 2 presents a summary of findings of the organisational paradoxes in lean and their underlying tensions, defensive mechanisms, managerial responses and outcomes.

\section{Insert *Table 2. Summary of the empirical findings* about here}

\section{Cross case analysis, discussions and implications}

Through our analysis, we came to view issues and intricacies of lean implementation located in core activities of the three organisations and reflected on three types of paradoxes: organising, performing and belonging. As such, the cross-case analysis of the three organisational paradoxes in lean and their underlying tensions, defensive mechanisms, managerial actions and outcomes enabled us to formulate our contributions to lean theory and practice.

The first cross-pattern of this analysis is related to the opposition or resistance to lean implementation manifested by employees and middle managers in the three companies. Indeed, the analysis revealed that employees and managers had generally reacted negatively and even actively opposed lean initiatives mainly in the beginning of lean implementation. The investigation of the three organisational paradoxes in lean helped capture more of the complexity of individuals' responses to the proposed lean changes. It did so by adding clarity to the reasons for people to react negatively and oppose lean conversion. Indeed, the three types of organisational paradoxes in lean organising, performing and belonging - revealed three different motivations for people to oppose lean implementation. These are: (1) lean standards limit their autonomy (organising paradox), (2) lean standards clash with their work identity based on creative non-repetitive approaches to problem solving (belonging paradox), and (3) lean standards are time consuming and can shift focus from meeting projects deadlines (performing paradox). Moreover, each motivation required different types of managerial actions in order to reduce the resistance and facilitate lean transformation. 
The second cross pattern of this study is related to the role played by contextual factors such as the communication patterns of top management in influencing the outcomes of the organisational paradoxes in lean. Specifically, the analysis revealed that contradictory messages of top management (Companies A and B) regarding the resources and efforts invested in lean conversion had a negative impact on lean transformation. For instance, mixed and contradictory messages from top management had accentuated the performing paradox and increased frustrations among employees and middle managers. That is, on the one hand, top management had required that employees focus on both short term (daily projects) and long term (lean projects) objectives. Yet, on the other hand, top management was often pressing to meet daily project deadlines, to the detriment of lean projects without communicating or explaining to employees how to achieve both short and long term objectives. As a consequence, most employees were choosing the safe pole of the paradox, namely focusing on the short term objectives and delaying lean improvement projects. Indeed, paradoxical tensions may be nested across hierarchical levels (Andriopoulos and Lewis, 2010), and dealing with paradoxes is a long term effort (Poole and Van de Ven, 1989). Therefore, dealing more effectively with paradoxical tension, such as the performing paradox, should necessarily involve coordination and learning across hierarchical levels about the nature of the paradox and how to deal with it (Andriopoulos and Lewis, 2010; Smith and Lewis, 2011).

The third cross pattern of this study is related to the managerial responses to lean paradoxes. In this study, we identified managerial actions and responses such as employees' involvement, experimentation, facilitation of group discussions and coaching for dealing with the organising and belonging paradoxes in lean. As we attempted to make sense of this range of managerial responses and practices, we searched the extant learning literature and found that all these managerial practices share a common denominator. That is, facilitation of learning (Ellinger and Bostrom, 1999; Cao et al., 2012). As facilitators of learning, managers are expected to coach employees by questioning their mental frame and encouraging them to think through issues; managers are also expected to promote a learning environment and to involve others to facilitate learning (Ellinger and Bostrom, 1999; Cao et al., 2012). As a consequence, it is not surprising that the positive outcomes identified in this study are not easy to sustain as dealing with lean paradoxes involves a continuous and lengthy learning process for both managers and employees.

As a contribution to lean theory, this study adds clarity to the role of the organisational paradoxes in facilitating or hindering lean transformation. Indeed, the extant lean literature offers two different or 
even opposing views regarding paradoxical tensions in lean and their effects on organisational life. On the one hand, lean scholars have associated the organisational paradoxes in lean with a source of positive outcomes. For instance, Womack, Jones and Roos (1990) mention that while lean flow does indeed remove slack and waste, "lean production offers a creative tension in which workers have many ways to address challenges" (p. 101). Within the same context, Eisenhardt and Westcott (1988) argue that paradoxical tensions and conflicting goals in just-in-time create the motivation for change, and Osono et al. (2008) observe that Toyota actually thrives on paradoxes and uses them to energise itself.

On the other hand, lean scholars have emphasised that some lean configurations are likely to unbalance organisational tensions, resulting in negative outcomes, which hinder lean transformation. For instance, Lewis (2000a) finds evidence that lean efficiency can curtail the firm's ability to innovate, while de Treville and Anatonakis (2006) find evidence that excessive leanness seems to offset the positive effect of lean on workers' intrinsic motivation. Within the same context, Mullarkey et al. (1995) note that employees' resistance to just-in-time can intensify when elements such as multiskilling and job rotation in product-based team-working give rise to the contradictory perceptions of increased autonomy and increased control among employees. By deepening our understanding regarding the why and when the organisational paradoxes in lean entail positive or negative outcomes, this study contributes to lean theory as an attempt to reconcile the different and even opposing views held by lean scholars regarding the outcomes of the organizational paradoxes in lean.

As a contribution to lean practice, this study firstly concludes that the identification of the various types of paradoxes in lean enables managers to better understand the motivations for resistance to lean conversion and, as a consequence, take more effective actions for facilitating lean transformation. For instance, managers could focus on dealing with the belonging paradoxes when people have stronger attachment to their work identity or on the organising paradoxes when individuals value their work autonomy. As such, this study recommends that managers should not rush to action before understanding the different impacts of lean implementation on individuals within their organisations. By not rushing to action, managers are able to identify and understand the nature of tensions for each group of employees, and as a consequence, to facilitate lean transformation more effectively. Secondly, this study emphasises the role of lean managers as facilitators of learning. As facilitator of learning, managers should boost employees' involvement 
and participation in lean transformation. Employees' involvement must entail a greater bottom up participation in defining and adjusting the scope and pace of lean transformation. In other terms, managers should consider the bottom up participatory approach as facilitator for learning and change during lean transformation, which increases employees' involvement by enabling them to make better use of lean tools and adjust lean practices to work dynamics. Figure 2 provides a conceptual framework and a guide for practitioners that link lean change, the associated tools and practices, and the source of tensions and resistance to the recommended managerial actions.

\section{Insert *Figure 2. Conceptual framework linking Lean change}

\section{to Managerial actions* about here}




\section{Conclusions}

Through the investigation of the organisational paradoxes in lean, we sought to add clarity to the processes of lean transformation. This study has played an important role in helping to understand the complexity of lean implementation and consolidation, and how lean management skills need to develop. To avoid unexpected setbacks and negative dynamics, lean managers must understand the nature of lean paradoxes, their impact on individuals and organisations, and how to effectively manage tensions when they are made salient. More importantly, understanding how the paradoxes in lean are best managed requires continuous learning that helps to uncover the intricacies of lean transformation. As such, "failure cannot be seen as a foe in this environment because the management approaches largely focus on learning" (Jarvenpaa and Wernick, 2011).

To the best of our knowledge, this is the first exploratory study that uses the paradox lens as framework for increasing the understanding of the intricacies of lean transformation and the motivations for people to resist lean implementation. As for future research opportunities, we recommend doing more qualitative and quantitative studies in order to consolidate the findings of this study by investigating the organizational paradoxes in lean in more companies. Moreover, these studies could attempt to identify the learning paradox in lean, which was not possible to track and validate empirically in this study. Future research could also expand and consolidate the repertoire of managerial responses used for dealing with tensions and paradoxes outside the continuous improvement practices of lean (Langstrand and Drotz, 2015). 


\section{References}

Adler, P. S., Goldoftas, B. and Levine, D. I. (1999), "Flexibility versus Efficiency? A Case Study of Model Changeovers in the Toyota Production System”, Organization Science, Vol. 10 No.1, pp. 4368.

Adler P. S. and Borys B. (1996), "Two types of bureaucracy: Enabling and coercive”, Administrative Science Quarterly, Vol. 41, pp. 61-89.

Andriopoulos, C., and Lewis, M. W. (2009), "Exploitation exploration tensions and organizational ambidexterity: Managing paradoxes of innovation”, Organization Science, Vol. 20 No. 4, pp. 696717.

Argyris, C. (1988), “Crafting a theory of practice: The case of organizational paradoxes”, In Quinn R. and Cameron K. (Eds.), Paradox and transformation: Toward a theory of change in organization and management, Ballinger, Cambridge, MA, pp. 255-278.

Bouas, K. S. and Komorita, S. S. (1996), “Group discussion and cooperation in social dilemmas”, Personality and Social Psychology Bulletin, Vol. 22, pp. 1144-1150.

Cao, R., Chuah, K. B., Chau, Y. C., Kwong, K. F. and Law, M. Y. (2012), "The role of facilitators in project action learning implementation”, The Learning Organization, Vol. 19 No. 5, pp. 414-427.

Cooney, R. (2002), "Is lean a universal production system? Batch production in the automotive industry", International Journal of Operations and Production Management, Vol. 22 No. 10, pp. $1130-1147$.

Cullinane, S.J, Bosak, J., Flood, P. C. and Demerouti, E. (2013), “Job design under lean manufacturing and its impact on employee outcomes", Organizational Psychology Review, Vol. 3 No. 1, pp. 41-61.

Cyert, R. M. and March, J. G. (1963), A behavioral theory of the firm, Prentice-Hall, Englewood Cliffs, N.J.

Dankbaar, B. (1997), "Lean production: Denial, confirmation or extension of sociotechnical systems design?", Human Relations, Vol. 50 No. 5, pp. 567-583. 
Denison, D.R., Hooijberg, R. and Quinn, R.E. (1995), "Paradox and performance: toward a theory of behavioral complexity in managerial leadership", Organization Science, Vol. 6 No. 5, pp. 52440.

de Treville, S. and Antonakis, J. (2006), "Could lean production job design be intrinsically motivating? Contextual, configurational, and levels-of-analysis issues", Journal of Operations Management, Vol. 24 No. 2, pp. 99-123.

Eisenhardt, K.M. (1989), "Building theories from case study research", Academy of Management Review, Vol. 14 No. 4, pp. 532-550.

Eisenhardt K. M. and Westcott B. J. (1988), "Paradoxical demands and the creation of excellence: The case of Just-in-Time manufacturing”, In Quinn R. and Cameron K. (Eds.), Paradox and transformation: Toward a theory of change in organization and management, Ballinger, Cambridge, MA, pp. 169-193.

Ellinger, A. D. and Bostrom, R. P. (1999), "Managerial coaching behaviors in learning organizations", Journal of Management Development, Vol. 18 No. 9, pp. 752-771.

Foropon, C. and McLachlin, R. (2013), "Metaphors in operations management theory building", International Journal of Operations and Production Management, Vol. 33 No. 2, pp. 181-196.

Glaser, B.G. and Strauss, A.L. (1967), The discovery of Grounded Theory: Strategies for qualitative research, Aldine Publishing Company: Chicago.

Glew, D., O'Leary-Kelly, A., Griffin, R. and Van Fleet, D. (1995), "Participation in Organizations: A Preview of the Issues and Proposed Framework for Future Analysis", Journal of Management, Vol. 21 No. 3, pp. 395-421.

Green, J. C., Lee, J. and Kozman, T. A. (2010), "Managing lean manufacturing in material handling operations”, International Journal of Production Research, Vol. 48 No. 10, pp. 2975-2993.

Hart, V., Blattner, J., and Leipsic, S. (2001), “Coaching versus therapy: A perspective”. Consulting Psychotherapy Journal: Practice and Research, Vol. 53, pp. 229-237. 
Hines, P., Holweg, M. and Rich, N. (2004), "Learning to evolve: A review of contemporary lean thinking", International Journal of Operations and Production Management, Vol. 24 No. 1, pp. 994 -1011 .

Jarvenpaa, S.L. and Wernick A. (2011), "Paradoxical tensions in open innovation networks", European Journal of Innovation Management, Vol. 14 No. 4, pp. 521-48.

Jarzabkowski, P., Lê, K. J. and Van de Ven, A. H. (2013), "Responding to competing strategic demands: How organizing, belonging, and performing paradoxes coevolve”. Strategic

Organization, Vol. 11 No. 3, pp. 245-280.

Karlsson, C. and Åhlström, P. (1996), “The difficult path to lean product development”, Journal of Product Innovation Management, Vol. 13, pp. 283-295.

Kvale, S. (1983), “The Qualitative Research Interview: A Phenomenological and a Hermeneutical Mode of Understanding”, Journal of phenomenological psychology, Vol. 14, pp. 171-196.

Langstrand, J. and Drotz, E. (2015), “The rhetoric and reality of Lean: a multiple case study", Total Quality Management \& Business Excellence, DOI:10.1080/14783363.2015.1004307

Lee, G., Bennett, D. and Oakes, I. (2000), “Technological and organizational change in small- to medium-sized manufacturing companies: A learning organization perspective", International Journal of Operations and Production Management, Vol. 20 No. 5, pp. 549-572.

Lewis, M. A. (2000a), "Lean production and sustainable competitive advantage”, International Journal of Operations and Production Management, Vol. 20 No. 8, pp. 959-978.

Lewis, M. W. (2000b), “Exploring paradox: Toward a more comprehensive guide”, Academy of Management Review, Vol. 25 No. 4, pp. 760-776.

Lincoln, Y. S., and Guba, E. G. (1985), Naturalistic Inquiry. Sage publications, Beverly Hills, California.

Locke, E. A., and Latham, G. P. (1990), A theory of goal setting and task performance, PrenticeHall, Englewood Cliffs, NJ.

Lüscher, L. and Lewis, M. (2008), “Organizational change and managerial sensemaking: Working through paradox", Academy of Management Journal, Vol. 51 No. 2, pp. 221-240. 
Miles, M.B. and Huberman, A.M. (1994), Qualitative data analysis: An expanded sourcebook, Sage publication, Thousand Oaks.

Modig, N. and Åhlström, P. (2012), This is lean, Bulls Graphics Press, Halmstad, Sweden.

Mullarkey, S., Jackson, P.R. and Parker, S.K. (1995), "Employee reactions to JIT manufacturing practices: a two-phase investigation", International Journal of Operations and Production Management, Vol. 15 No. 11, pp. 62-79.

Murnigham, J. K., and Conlon, D. (1991), “The dynamics of intense work groups: A study of British string quartets", Administrative Science Quarterly, Vol. 36, pp. 165-186.

Nawanir, G., Teong, L. M. and Othman, S. N. (2013), "Impact of lean practices on operations performance and business performance: Some evidence from Indonesian manufacturing companies", Journal of Manufacturing Technology Management, Vol. 24 No. 7, pp. 1019-1050.

Noe, R. A. (2001), Employee training and development, McGraw-Hill, New York, NY.

Osono, E., Shimizu, N. and Takeuchi, H. (2008), Extreme Toyota, John Wiley and Sons: Hoboken, NJ.

Pavnaskar, S. J., Gershenson, J. K. and Jambekar, A. B. (2003), "Classification scheme for lean manufacturing tools", International Journal of Production Research, Vol. 41 No. 13, pp. 30753090 .

Poole, M. S. and Van de Ven, A. H. (1989), "Using paradox to build management and organization theories", Academy of Management Review, Vol. 14 No. 4, pp. 562-578.

Putnam, L. L. (1986), “Contradictions and paradoxes in organizations”. In Thayer L. (Ed.), Organization communications: Emerging perspectives, Ablex Publishing, Norwood, NJ, pp. 151167.

Quinn, R and Cameron, K. (1988), Paradox and transformation: Toward a theory of change in organization and management, Ballinger, Cambridge, MA.

Repenning, N. and Sterman, J. (2001), "Nobody ever gets credit for fixing problems that never happened: Creating and sustaining process improvement”, California Management Review, Vol. 43 No. 4, pp. 64-88. 
Rerup, C. and Feldman M. S. (2011), "Routine as a source of change in organizational schemata: The role of trial-and-error learning”, Academy of Management Journal, Vol. 54 No. 3, pp. 577-610.

Saurin, T. A., Marodin, G. A.and Ribeiro, J. L. D. (2011), “A framework for assessing the use of lean production practices in manufacturing cells", International Journal of Production Research, Vol. 49 No. 11, pp. 3211-3230.

Segers J., Vloeberghs, D. L and Henderickx, E. (2011), "Structuring and Understanding the Coaching Industry: The Coaching Cube", Academy of Management Learning and Education, Vol. 10 No. 2, pp. 204-221.

Sezen, B., Karakadilarb, I. S., and Buyukozkanc, G. (2012), "Proposition of a model for measuring adherence to lean practices: applied to Turkish", International Journal of Production Research, Vol. 50 No. 14, pp. 3878-3894.

Shadur, M. A., Kienzle, R., and Rodwell, J. J. (1999), “The relationship between organizational climate and employee perceptions of involvement: The importance of support", Group and Organization Management, Vol. 24 No. 4, pp. 479-503.

Shah, R., and Ward, P. (2003), "Lean manufacturing: Context, practice bundles, and performance", Journal of Operations Management, Vol. 21 No. 2, pp. 129- 149.

Smeds, R. (1994), "Managing change towards lean enterprises”, International Journal of Operations and Production Management, Vol. 14 No. 3, pp. 66-82.

Smith, W. K. and Lewis, M. W. (2011), “Toward a theory of paradox: A dynamic equilibrium model of organizing", Academy Management Review, Vol. 36 No. 2, pp. 381-403.

Smith, K. and Berg, D. (1987), Paradoxes of group life, Josey-Bass, San Francisco.

Vince, R., and Broussine, M. (1996), "Paradox, defence and attachment: Accessing and working with emotions and relations underlying organizational change”, Organization Studies, Vol. 17, pp. $1-21$.

West, P. and Burnes, B. (2000), “Applying organizational learning: lessons from the automotive industry", International Journal of Operations and Production Management, Vol. 20 No. 10, pp. 1236-1251. 
1

2

3

4

5

6

7

8

9

10

11

12

13

14

15

16

17

18

19

20

21

22

23

24

25

26

27

28

29

30

31

32

33

34

35

36

37

38

39

40

41

42

43

44

45

46

47

48

49

50

51

52

53

54

55

56

57

58

59

60

Womack, J. and Jones D. T. (2003), Lean Thinking: Banish waste and create wealth for your corporation, Simon and Schuster: New York, NY.

Womack, J., Jones, D.T. and Roos, D. (1990), The Machine That Changed the World, Rawson Associates: New York, NY.

Yin, R. (2009), Case study research: Design and methods, Sage, Los Angeles. 


\section{Figure 1 - The analytical framework}

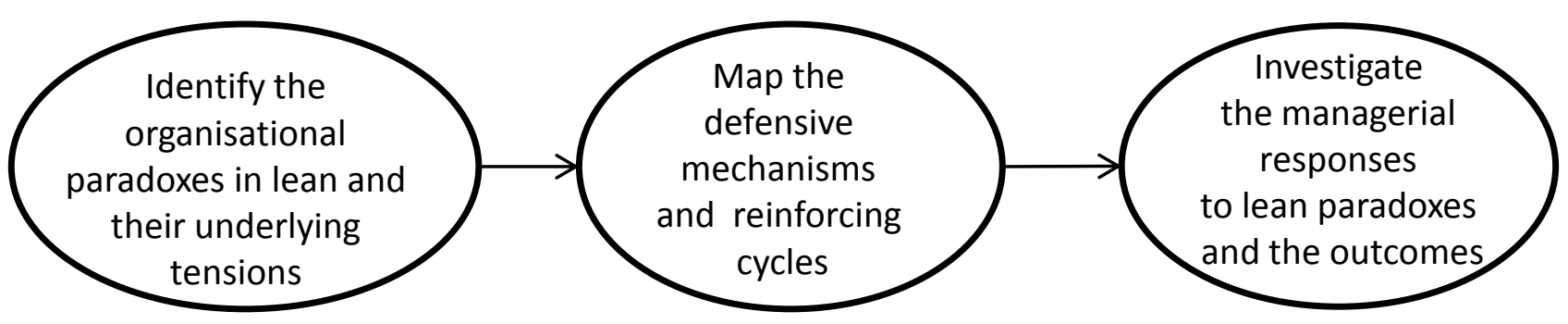


Figure 2. Conceptual framework linking lean change to managerial actions

\begin{tabular}{|c|c|c|c|}
\hline \multicolumn{4}{|c|}{ Lean change and the associated tools and practices } \\
\hline $\begin{array}{l}\text { Emphasize work } \\
\text { standards }\end{array}$ & $\begin{array}{l}\text { Make the process } \\
\text { flow }\end{array}$ & $\begin{array}{l}\text { Increase cross- } \\
\text { fuctional cooperation }\end{array}$ & $\begin{array}{l}\text { Roll out lean } \\
\text { improvement } \\
\text { structures }\end{array}$ \\
\hline $\begin{array}{l}\text { Operating standards, } \\
\text { 5S, Value stream } \\
\text { mapping }\end{array}$ & $\begin{array}{c}\text { One-piece flow, Load } \\
\text { levelling }\end{array}$ & $\begin{array}{c}\text { Cross-functional } \\
\text { teams }\end{array}$ & $\begin{array}{l}\text { All lean tools and } \\
\text { practices }\end{array}$ \\
\hline \multicolumn{4}{|c|}{ Sources of tensions and resistance } \\
\hline $\begin{array}{l}\text { Tension between } \\
\text { standards and } \\
\text { autonomy/creativity }\end{array}$ & $\begin{array}{l}\text { Tension between } \\
\text { roles: process } \\
\text { knowledge versus } \\
\text { technical knowledge }\end{array}$ & $\begin{array}{l}\text { Tension between } \\
\text { working in teams and } \\
\text { working alone }\end{array}$ & $\begin{array}{l}\text { Tension between short } \\
\text { term and long term } \\
\text { objectives }\end{array}$ \\
\hline \multicolumn{4}{|c|}{ Managerial actions } \\
\hline $\begin{array}{c}\text { Experimentation and } \\
\text { adjustment of lean } \\
\text { standards to local } \\
\text { needs }\end{array}$ & $\begin{array}{l}\text { Coaching and Mentoring } \\
\text { to influence the } \\
\text { cognition and behaviors } \\
\text { of individuals }\end{array}$ & $\begin{array}{l}\text { Facilitation of group } \\
\text { discussions and } \\
\text { reducing the fear of } \\
\text { exploitation }\end{array}$ & $\begin{array}{l}\text { Long term Commitment: } \\
\text { Effective allocation of } \\
\text { resources and worktime } \\
\text { to lean change, and } \\
\text { alignment with annual } \\
\text { performance appraisal }\end{array}$ \\
\hline
\end{tabular}


Table 1. Case companies, lean tools and data sources

\begin{tabular}{|c|c|c|c|}
\hline & $\begin{array}{l}\text { Brief description } \\
\end{array}$ & Lean tools & Data sources \\
\hline 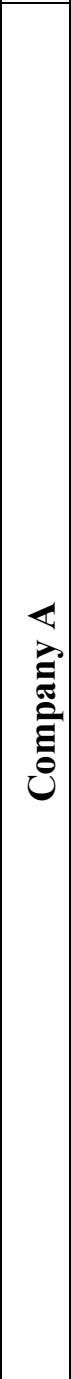 & $\begin{array}{l}\text { Company A is a global healthcare company with more than } 50 \\
\text { years of innovation and leadership in healthcare. Headquartered in } \\
\text { Denmark, Company A employs approximately } 32,000 \text { employees } \\
\text { in } 75 \text { countries, and markets its products in almost } 180 \text { countries. } \\
\text { It introduced first lean in its manufacturing operations in Denmark } \\
\text { and abroad and, then it decided to implement lean in its Research } \\
\text { and Development (R\&D) unit in Denmark. The implementation of } \\
\text { lean in R\&D was challenging in a sense that, at the time of lean } \\
\text { implementation in R\&D, no other company in Denmark have had } \\
\text { experience in implementing lean in its Research and Development } \\
\text { unit. } \\
\text { Within R\&D, the data were collected in Operations and Support } \\
\text { department. This department gives operational support during the } \\
\text { manufacturing and testing of new products. In order to increase } \\
\text { efficiency, the department decided to employ intensively } \\
\text { Operating standards and } 5 \mathrm{~S} \text { as tools for bolstering discipline. As } \\
\text { consequence, the tension between standard and autonomy had } \\
\text { accentuated in the R\&D department as people considered that } \\
\text { autonomy and creativity - core competences of an R\&D } \\
\text { department - could be hampered. }\end{array}$ & $\begin{array}{l}\text { Operating } \\
\text { standards, } \\
\text { value stream } \\
\text { mapping, } \\
\text { cross- } \\
\text { functional } \\
\text { teams, visual } \\
\text { management } \\
\text { and } 5 \mathrm{~S} \text {. }\end{array}$ & $\begin{array}{l}\text { Nine interviews } \\
\text { with employees } \\
\text { from different } \\
\text { functions and } \\
\text { hierarchical } \\
\text { levels. Site visits } \\
\text { and discussions } \\
\text { with employees } \\
\text { and managers } \\
\text { involved in lean } \\
\text { implementation. }\end{array}$ \\
\hline
\end{tabular}




\begin{tabular}{|c|c|c|c|}
\hline 己. & $\begin{array}{l}\text { Company B has been part of the public transport system in } \\
\text { Denmark since } 1997 \text { and today it is considered one of the largest } \\
\text { public transport companies in Denmark, with } 4,300 \text { employees. In } \\
\text { order to gain the five-year contract with Copenhagen municipality, } \\
\text { Company B has to meet some performance criteria such as } \\
\text { punctuality and passenger satisfaction. } \\
\text { Two groups of employees had to work closely in order to meet } \\
\text { rigorous performance criteria: the mechanics in the shop floor and } \\
\text { the traffic planners. Among other lean tools, the company relied } \\
\text { heavily on cross-functional teams composed of both groups of } \\
\text { employees to order to meet or exceed performance criteria. The } \\
\text { cross functional cooperation has accentuated the identity tensions } \\
\text { between mechanics and traffic planners as people had to comply } \\
\text { with different work cultures in order to achieve multiple } \\
\text { performance criteria such as quality and punctuality. }\end{array}$ & $\begin{array}{l}\text { 5S, operating } \\
\text { standards, } \\
\text { value stream } \\
\text { mapping, } \\
\text { cross- } \\
\text { functional } \\
\text { teams, and } \\
\text { visual } \\
\text { management. }\end{array}$ & $\begin{array}{l}\text { Seven } \\
\text { interviews with } \\
\text { employees, } \\
\text { managers and } \\
\text { senior } \\
\text { managers. Site } \\
\text { visits, } \\
\text { company's } \\
\text { presentation, } \\
\text { discussions with } \\
\text { employees and } \\
\text { managers during } \\
\text { lean } \\
\text { implementation. }\end{array}$ \\
\hline
\end{tabular}




\begin{tabular}{|c|c|c|c|}
\hline 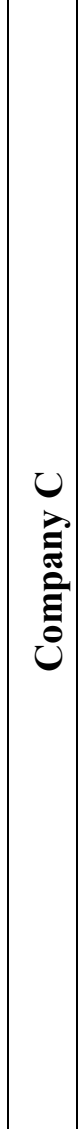 & $\begin{array}{l}\text { Company } \mathrm{C} \text { is one of the biggest financial companies in Denmark, } \\
\text { with more than } 20,000 \text { employees in } 15 \text { countries. The company } \\
\text { offers a complete range of banking products and services for both } \\
\text { Danish and international customers. The unit at Company C where } \\
\text { the data were collected chose to implement lean in its back office } \\
\text { operations in order to increase the productivity of the case } \\
\text { handling process ( } 20 \% \text { increase). } \\
\text { The company chose to implement lean flow/Load levelling in } \\
\text { order to identify and eliminate wastes, and increase the efficiency } \\
\text { of the claim handling process. In order to succeed in the } \\
\text { implementation of lean flow, team leaders had to take on new } \\
\text { roles based on process knowledge (e.g. takt time and bottlenecks) } \\
\text { rather than the traditional roles based on technical knowledge } \\
\text { (claims handling rules and procedures). This fact had frequently } \\
\text { ignited the belonging tensions as people valued the old roles, } \\
\text { source of their prestige within the organization. }\end{array}$ & $\begin{array}{l}\text { Operating } \\
\text { standards, } \\
\text { value stream } \\
\text { mapping, } \\
\text { lean flow and } \\
\text { load } \\
\text { levelling, } \\
\text { cross- } \\
\text { functional } \\
\text { teams, and } \\
\text { visual } \\
\text { management. }\end{array}$ & $\begin{array}{l}\text { Eleven } \\
\text { interviews with } \\
\text { employees from } \\
\text { different } \\
\text { functions and } \\
\text { hierarchical } \\
\text { levels and with } \\
\text { consultants } \\
\text { involved in lean } \\
\text { transformation. } \\
\text { Site visits, } \\
\text { company's } \\
\text { presentations } \\
\text { and discussions } \\
\text { with participants } \\
\text { in lean } \\
\text { implementation. }\end{array}$ \\
\hline
\end{tabular}


Table 2. Summary of the empirical findings

\begin{tabular}{|c|c|c|c|}
\hline Organizing paradox & Performing paradox & \multicolumn{2}{|c|}{ Belonging paradox } \\
\hline $\begin{array}{l}\text { Lean operating } \\
\text { standards vs. } \\
\text { Autonomy: Organising } \\
\text { paradox in companies } \\
\text { A, B, and C / (Number } \\
\text { of informants) }\end{array}$ & $\begin{array}{l}\text { Work harder vs. Work } \\
\text { smarter: Performing } \\
\text { paradox in companies A, } \\
\text { B / (Number of } \\
\text { informants) }\end{array}$ & $\begin{array}{l}\text { Functional role vs. } \\
\text { Team role: Belonging } \\
\text { paradox in companies } \\
\text { A and B / (Number of } \\
\text { informants) }\end{array}$ & $\begin{array}{l}\text { Old role vs. New role: } \\
\text { Belonging paradox in } \\
\text { company C / (Number } \\
\text { of informants) }\end{array}$ \\
\hline $\begin{array}{l}\text { Underlying tensions: } \\
\text { Systemic contradictions } \\
\text { are created as companies } \\
\text { implement competing } \\
\text { designs (24) }\end{array}$ & $\begin{array}{l}\text { Underlying tensions: } \\
\text { Contradictory or mixed } \\
\text { messages create and } \\
\text { accentuate this paradox } \\
(15)\end{array}$ & $\begin{array}{l}\text { Underlying tensions: } \\
\text { Two functions } \\
\text { cultivating different } \\
\text { values and identities (8) }\end{array}$ & $\begin{array}{l}\text { Underlying tensions: } \\
\text { Struggle between the old } \\
\text { and the new roles (6) }\end{array}$ \\
\hline $\begin{array}{l}\text { Defensive mechanisms: } \\
\text { People often attempted to } \\
\text { emphasise the } \\
\text { shortcomings of lean } \\
\text { standards (24) }\end{array}$ & $\begin{array}{l}\text { Defensive mechanisms: } \\
\text { Employees chose the safe } \\
\text { option: work harder }(15)\end{array}$ & $\begin{array}{l}\text { Defensive mechanisms: } \\
\text { Blame the other } \\
\text { function for the } \\
\text { problems (8) }\end{array}$ & $\begin{array}{l}\text { Defensive mechanisms: } \\
\text { Value the old role which } \\
\text { has been the source of } \\
\text { prestige within the } \\
\text { organisation (6) }\end{array}$ \\
\hline $\begin{array}{l}\text { Managerial responses: } \\
\text { Employee involvement } \\
\text { and experimentation (19) }\end{array}$ & $\begin{array}{l}\text { Managerial responses: } \\
\text { Temporal separation, } \\
\text { spatial separation and goal } \\
\text { setting (11) }\end{array}$ & $\begin{array}{l}\text { Managerial responses: } \\
\text { Facilitation of group } \\
\text { discussions (8) }\end{array}$ & $\begin{array}{l}\text { Managerial responses: } \\
\text { Coaching and mentoring } \\
\text { (6) }\end{array}$ \\
\hline $\begin{array}{l}\text { Outcomes: } \\
\text { More acceptance as the } \\
\text { either/or mental model is } \\
\text { replaced by both/and } \\
\text { logic. However, some } \\
\text { employees still seek full } \\
\text { autonomy (19) }\end{array}$ & $\begin{array}{l}\text { Outcomes: } \\
\text { People realise that work } \\
\text { smarter is beneficial in the } \\
\text { long run. However, } \\
\text { constant pressure from } \\
\text { management makes the } \\
\text { work harder option prevail } \\
\text { (11) }\end{array}$ & $\begin{array}{l}\text { Outcomes: } \\
\text { More understanding of } \\
\text { each other's challenges } \\
\text { and fewer we/they } \\
\text { distinctions (8) }\end{array}$ & $\begin{array}{l}\text { Outcomes: } \\
\text { Some employees take on } \\
\text { the new role successfully } \\
\text { while others are moved } \\
\text { to different positions (6) }\end{array}$ \\
\hline
\end{tabular}

